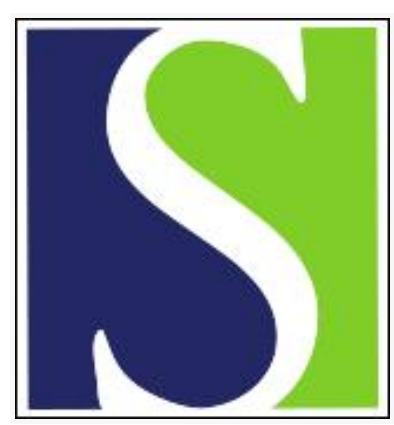

Scand J Work Environ Health 1989;15(5):345-352

https://doi.org/10.5271/sjweh.1839

Issue date: Oct 1989

Spontaneous abortions and congenital malformations among the wives of men occupationally exposed to organic solvents.

by Taskinen H, Anttila A, Lindbohm ML, Sallmen M, Hemminki K

Affiliation: Institute of Occupational Health, Helsinki, Finland.

The following articles refer to this text: 2013;39(4):335-342;

2013;39(4):325-334

This article in PubMed: www.ncbi.nlm.nih.gov/pubmed/2799322 


\title{
Spontaneous abortions and congenital malformations among the wives of men occupationally exposed to organic solvents
}

\author{
by Helena Taskinen, MD, Ahti Anttila, MA, Marja-Liisa Lindbohm, MA, Markku Sallmén, BSc, \\ Kari Hemminki, MD ${ }^{1}$
}

\begin{abstract}
TASKINEN H, ANTTILA A, LINDBOHM M-L, SALLMÉN M, HEMMINKI K. Spontaneous abortions and congenital malformations among the wives of men occupationally exposed to organic solvents. Scand J Work Environ Health 1989;15:345-352. A case-referent study nested in a cohort monitored biologically for exposure to six organic solvents (styrene, toluene, xylene, tetrachloroethylene, trichloroethylene, and 1,1,1-trichloroethane) was conducted to investigate the effects of paternal exposure on pregnancy outcome. The pregnancies were identified from medical registers. The exposures of the men during the spermatogenesis preceding the pregnancies and of the women during the first trimester of the pregnancies were obtained with questionnaires, and the available biological monitoring measurements were used in the exposure assessment. Factors which significantly increased the odds ratio of spontaneous abortion were paternal exposure to organic solvents in general, high/frequent exposure to toluene or miscellaneous organic solvents (including thinners), and maternal heavy lifting. No significant association between paternal or maternal exposure and congenital malformations was found, but because of the few cases no firm conclusions can be drawn.
\end{abstract}

Key terms: biological monitoring, paternal exposure, styrene, tetrachloroethylene, toluene, trichloroethylene, xylene, 1,1,1-trichloroethane.

Organic solvents are commonly used in various industries, but information on the reproductive effects of paternal exposure is limited. Infertility (1), low birthweight (2), and congenital malformations of the offspring $(3,4)$ have been reported in connection with paternal exposure to organic solvents. Methodological difficulties in reliably measuring the outcome of the pregnancy and the occupational exposures have complicated such studies.

Paternal effects on a pregnancy and the fetus are believed to be caused by mutagenic or toxic mechanisms. Of the studied solvents, tetrachloroethylene and the metabolite of styrene, styrene oxide, have been classified as animal carcinogens (5). Mutagenicity tests have been negative or inconclusive for ethylene glycol derivatives, but testicular atrophy and pathological changes in the semen of exposed male animals have been found (6). In addition, in human studies, changes in semen have been found (7). Changes indicating mutagenic effects in cultured lymphocytes and in sperm cells have been found among metal workers exposed to trichloroethylene (8). Xylene and toluene have lacked a demonstrable mutagenic/genotoxic potential in various tests $(9,10)$. Increases and decreases in the plasma levels of the follicle-stimulating hormone of toluene-exposed men have been reported, and they indicate some effect on male reproductive health $(11,12)$.

In this case-referent study we investigated the effects of paternal exposure to organic solvents on pregnan-

\footnotetext{
I Institute of Occupational Health, Helsinki, Finland.
}

Reprint requests to: Dr $\mathrm{H}$ Taskinen, Institute of Occupational Health, Topeliuksenkatu 41 a A, SF-00250 Helsinki, Finland. cy outcome. We also tried to determine whether any single organic solvent or a group of such solvents could be identified as harmful. The register of biological monitoring measurements was applied for six commonly used organic solvents (styrene, toluene, xylene, tetrachloroethylene, trichloroethylene, and 1,1,1-trichloroethane) to ensure reliable information on exposure. Information on pregnancy outcome was obtained from medical registers. The results suggest that preconceptional paternal exposure to organic solvents may increase the risk of spontaneous abortion.

\section{Subjects and methods}

The source of the study population was workers ever monitored for organic solvent exposure by the Finnish Institute of Occupational Health during 1965 through 1983. The exposure measurements included were the mandelic acid concentration in the urine for styrene, trichloroacetic acid in the urine for trichloroethylene, methylhippuric acid in the urine for xylene, and the concentration of tetrachloroethylene, toluene and 1,1,1-trichloroethane in the blood. There were 13132 exposure measurements conducted on about 6000 men.

Information about the marriages and the wives of the monitored men was obtained from the Finnish Population Register Centre with the use of the personal identification numbers of the men in question. The information also yielded the personal identification number of their wives, and this number was used to gain data from the pregnancy outcome registers. (See the following text.) Only men in their first marriage dur- 
ing the year of inquiry (1985) and with wives $18-40$ years of age at the end of the first trimester of pregnancy were included. Only pregnancies which had begun during the marriages or no more than nine months before them were accepted. About $19 \%$ (774 of 4035) of the pregnancies of the wives were excluded because they had begun more than nine months before the marriages or after a divorce. Among these were 77 spontaneous abortions.

The data on the medically diagnosed pregnancies of the wives were retrieved from the Hospital Discharge Register maintained by the National Board of Health. Data on spontaneous abortions treated in the hospital polyclinics were collected separately from the hospitals. In this data base the rate of spontaneous abortion among all recognized pregnancies (= spontaneous abortions, induced abortions, and births) varied from $7.8 \%$ in 1973 to $10.2 \%$ in 1983 (13). For the pregnancies of this study the rate of spontaneous abortion was $8.8 \%$. The following codes of the eighth revision of the International Classification of Diseases (ICD) were used for pregnancies during 1973-1983 in the record linkage: $650-662$ for delivery and 643 and 645 for spontaneous abortion.

The data on congenital malformations during 1973-1982 were taken from the Finnish Register of Congenital Malformations, to which it has been compulsory to notify congenital malformations identified during the first year of life. Studies comparing the registered data with hospital information have revealed a reporting and detection failure rate of about $30 \%$ (14). The failure rate varies by the type of the defect, minor malformations being particularly underreported.

The descriptions of the contents, coverage, and reliability of both of the aforementioned registers have been published earlier $(13,14)$.

This study had a case-referent design. The wives with a spontaneous abortion or with a congenitally malformed child were defined as cases. If the wife had two or more spontaneous abortions, only one was randomly selected. Three referents were selected for each spontaneous abortion and five for each congenital malformation from the wives who had given birth. Only those women who did not have a registered spontaneous abortion or a registered malformed child during the study period (1973-1983) were eligible as referents. The referents were selected by computer so that the ages of the case mother and the referent at the time of conception were as similar as possible, at least within 30 months. Only one pregnancy per woman was included.

Separate questionnaires were mailed (January 1986) in the same envelope to both spouses of the case and reference families to obtain data on occupational exposures related to the study pregnancy. The men were requested to give information on employment, occupation, and workplace during the year of conception. They were requested to describe their work tasks and potential changes in them in detail and the months of changes during that year. This procedure was necessary to certify the exposure situation for the spermatogenesis period. A new questionnaire was mailed if sufficient information was not obtained in the first one. The men were also asked to report whether they had handled any of the monitored solvents or other solvents (eg, white spirit, petroleum benzine, thinner, acetone). Almost 300 tradenames of different solvents were reported by the study subjects. The chemical composition of the commercial products was checked from the safety sheets or the Register of Safety Information on Chemical Products. The frequency of the usage (daily, 1-4 d a week, less than once a week) and exposure to gases, vapors, dusts, fumes, other chemicals, or radiation in the work was requested. Questions concerning earlier employment, chronic diseases, smoking, and alcohol consumption were also included.

The information on occupational and life-style exposures during the first trimester of pregnancy was requested from the wife. Questions were asked about heavy lifting and acute febrile diseases. The pregnancy history was also recorded. Only those couples who reported the pregnancy found in the registers were included in the analysis.

The man's exposure was assessed for the time of the calculated spermatogenesis ( 80 calendar days) preceding the study pregnancy without the case-referent status being known. The assessment was based on the occupation, job description, reported solvent or other chemical usage, and biological monitoring data. The likelihood of exposure was categorized as follows: $u n-$ exposed, when the worker reported no exposure and he was not monitored in the same job; potentially exposed, if, according to the job description, solvent usage was possible (eg, gluing), but no clear solvent exposure was reported and no exposure measurement had been conducted; likely exposed, when the job implied solvent exposure and there were exposure measurements from the same job or solvent exposure was reported.

The quantity of the exposure was estimated on the basis of the reported frequency of the use of solvents and on the biological monitoring data, when available. Only a few measurements had been conducted during the time of spermatogenesis (17 measurements) or during the preceding year (44 measurements). However, biological measurements of solvents illustrate the exposure of very short time (the same or the previous day). Thus exposure classification was mainly based on the job description, and monitoring results supported the information. The exposure was defined as "high/frequent"' if the worker handled solvents daily or if the biological measurements indicated clear occupational exposure (above the reference values for the general population). The exposure was defined as "intermediate" when the solvent was used $1-4 \mathrm{~d}$ a week and the biological measurements indicated intermediate/low exposure. If solvent handling occurred more 
rarely, the exposure was defined as "low/rare." Foremen who did not take part in the manufacturing process but were present in the work area fell into the category below the one assigned to them on the basis of the frequency of exposure. If the worker's exposure to solvents in general was likely, but no specific solvent could be identified, he was placed into the category "exposed to solvents in general" in the final analysis. However, as regards the specific solvent variable, such a worker fell into the unexposed category.

Many workers reported exposure to a "thinner" without specifying the chemical composition of the product. According to the safety sheets, thinners are organic solvent mixtures which may contain xylene and/or toluene and other organic solvents. Therefore, reported thinner exposure was considered as likely in the variable of miscellaneous solvents and potential in the xylene and toluene variables. Exposure to other toxic chemicals and carcinogens was assessed blindly on the basis of the questionnaire information. A chemical was defined as a carcinogen if classified as a human carcinogen (group 1), a probable human carcinogen (group $2 \mathrm{~A}$ ), or a potential human carcinogen (group 2B) by the International Agency for Research on Cancer (5).

The woman's exposure was assessed similarly, but on the basis of the questionnaire information only. The lifting of heavy burdens during the first trimester of the pregnancy was classified according to a score variable over daily averages as follows: $5-9 \mathrm{~kg}=1$ point per lift, $10-19 \mathrm{~kg}=3$ points per lift, and $\geq 20 \mathrm{~kg}=5$ points per lift. The total score for the variable was obtained by summing the scores of lifts at work and at home.

With respect to spontaneous abortion the response rate of the cases was higher than that of the referents (136 of 172 or $79.1 \%$ and 370 of 505 or $73.3 \%$, respectively). Some variation was seen in the response rates in the subpopulations monitored for specific solvents. Among the cases the response rate was 95$74 \%$, and among the referents it was $85-70 \%$. The final analysis included the matched case-referent sets confirming the study pregnancy (120 cases and 251 referents) (table 1). The decrease in the numbers of the final material was mostly due to nonresponse. If a case did not respond, the three matched referents were also excluded. If none of the referents for a case responded, the case was excluded. Only one referent was excluded because it was not possible to estimate the exposure status due to insufficient information.

In the final material $61 \%$ of the men held (during the spermatogenesis period of the study) the same job in which they had been biologically monitored for solvent exposure. Some had changed jobs between the measurement and conception, and some had started to work with organic solvents after the study pregnancy. The information used in the classification is presented in detail in table 2. Exposure to organic solvents was considered likely for $85 \%$ of the cases and $73 \%$ of the referents; $60 \%$ of the cases and $45 \%$

Table 1. Formation of the final material in the study of spontaneous abortion.

\begin{tabular}{|c|c|c|c|c|c|c|}
\hline & \multicolumn{2}{|c|}{ Cases } & \multicolumn{2}{|c|}{ Referents } & \multicolumn{2}{|c|}{ Total } \\
\hline & N & $\%$ & $\mathrm{~N}$ & $\%$ & $\mathrm{~N}$ & $\%$ \\
\hline Total population & 172 & 100 & 505 & 100 & 677 & 100 \\
\hline $\begin{array}{l}\text { Respondents } \\
\text { ( } \% \text { of total) }\end{array}$ & 136 & 79.1 & 370 & 73.3 & 506 & 74.7 \\
\hline $\begin{array}{l}\text { Reported the } \\
\text { pregnancy of interest } \\
\text { (\% of respondents) }\end{array}$ & 122 & 89.7 & 369 & 99.7 & 491 & 97.0 \\
\hline $\begin{array}{l}\text { Final population for } \\
\text { the matched analysis } \\
(\% \text { of respondents) }\end{array}$ & 120 & 88.2 & 251 & 67.8 & 371 & 73.3 \\
\hline
\end{tabular}

Table 2. Information used for classifying the solvent exposure.

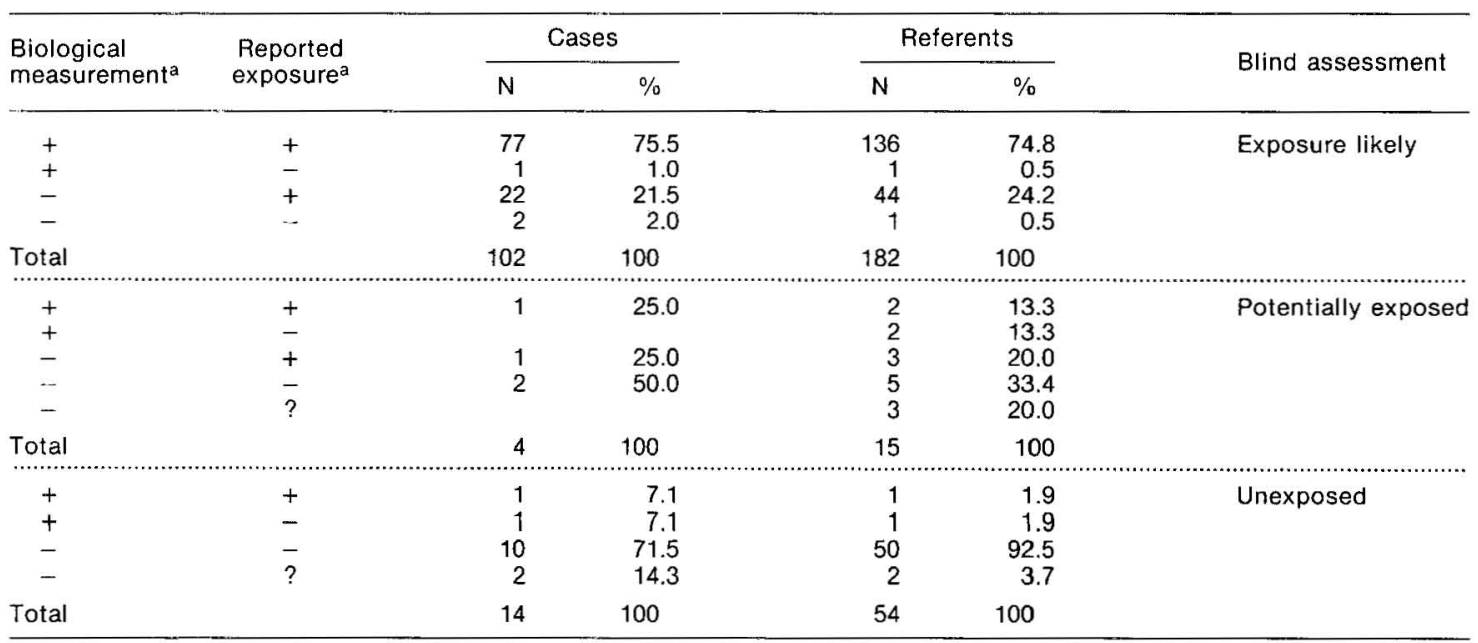

a $+=$ yes, $-=$ no, ? = uncertain information. 
of the referents fell into the high/frequent exposure category.

As an illustration of exposure to multiple solvents, three solvents have been presented in figure 1 . In the high/frequent exposure category there were 97 men exposed to toluene, xylene, or miscellaneous solvents. Only $25 \%$ (14 of 57) of the toluene-exposed men, $23 \%$

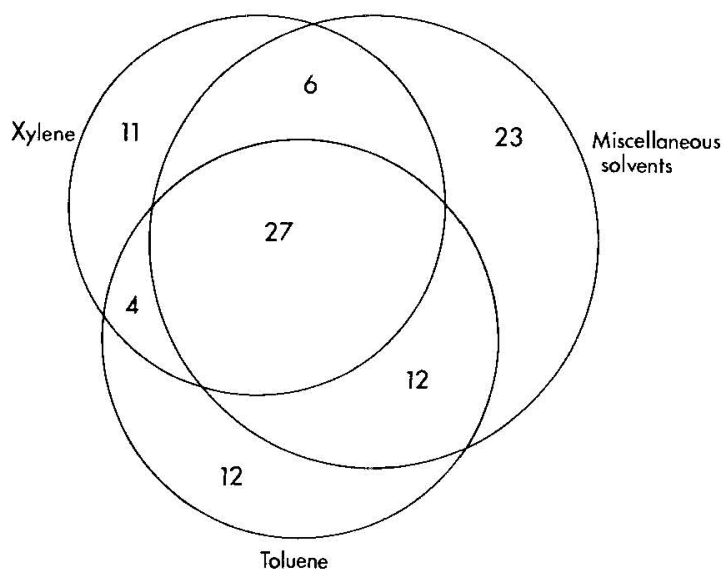

Figure 1. Schematic diagram of exposure to three different solvents at the high/frequent level.
(11 of 48) of the xylene-exposed men, and $34 \%$ (23 of 68) of the workers exposed to miscellaneous solvents were exposed to these solvents alone. Other workers were exposed to combinations of these three solvents, $28 \%$ (27 of 97 ) being exposed to all three solvents. Actually, the workers were also exposed to solvents other than the ones mentioned, and therefore a complex multiexposure situation was indicated for the workplaces.

The response rate in the congenital malformation part of the study was similar for the cases (25 of 33 or $75.8 \%$ ) and the referents (126 of 168 or $75.0 \%)$. All the respondents confirmed the study pregnancy. After the matching procedures, 25 cases and 96 referents remained in the final analysis. Paternal exposure to organic solvents was present in $72 \%$ of the cases and $73 \%$ of the referents. No case mother reported exposure to organic solvents.

The odds ratios of the medically recognized spontaneous abortions for the exposures of the male workers and their wives were estimated with the logistic regression model for individually matched data based on the conditional likelihood function. The statistical significance for separate variables was evaluated by comparing the respective standardized regression coefficients with a normal distribution (15).

Table 3. Odds ratio (OR) of spontaneous abortion for individual risk indicators - conditional logistic regression models, confounders not controlled. ( $95 \% \mathrm{Cl}=95 \%$ confidence interval)

\begin{tabular}{|c|c|c|c|c|}
\hline Risk indicator & Cases & Referents & OR & $95 \% \mathrm{Cl}$ \\
\hline \multicolumn{5}{|l|}{ Paternal exposure } \\
\hline Organic solvents & 103 & 182 & 2.7 & $1.3-5.6^{* *}$ \\
\hline Aromatic hydrocarbons ${ }^{a}$ & 77 & 135 & 1.6 & $1.0-2.4$ \\
\hline $\begin{array}{l}\text { Styrene }^{a} \\
\text { Toluene }^{a} \\
\text { Xylene }^{a}\end{array}$ & $\begin{array}{l}37 \\
48 \\
37\end{array}$ & $\begin{array}{l}66 \\
83 \\
61\end{array}$ & $\begin{array}{l}1.3 \\
1.5 \\
1.8\end{array}$ & $\begin{array}{l}0.8-2.1 \\
0.9-2.5 \\
1.1-3.2^{*}\end{array}$ \\
\hline Halogenated hydrocarbons ${ }^{a}$ & 31 & 61 & 1.1 & $0.6-1.8$ \\
\hline $\begin{array}{l}\text { Tetrachloroethylene }^{a} \\
\text { Trichloroethylene } \\
\text { 1,1,1-Trichloroethane }\end{array}$ & $\begin{array}{r}4 \\
17 \\
7\end{array}$ & $\begin{array}{l}17 \\
35 \\
16\end{array}$ & $\begin{array}{l}0.5 \\
1.0 \\
0.9\end{array}$ & $\begin{array}{l}0.2-1.5 \\
0.6-2.0 \\
0.3-2.3\end{array}$ \\
\hline Aliphatic hydrocarbons & 43 & 75 & 1.5 & $0.9-2.5$ \\
\hline Acetone & 33 & 68 & 1.0 & $0.6-1.7$ \\
\hline $\begin{array}{l}\text { Miscellaneous organic solvents } \\
\text { (including thinners) }\end{array}$ & 50 & 77 & 1.7 & $1.1-2.6^{*}$ \\
\hline Other chemicals & 27 & 64 & 0.8 & $0.5-1.5$ \\
\hline Carcinogens & 55 & 99 & 1.3 & $0.9-2.1$ \\
\hline Dusts & 88 & 160 & 2.3 & $1.2-4.3^{* *}$ \\
\hline Smoking & 56 & 143 & 0.6 & $0.4-1.0^{*}$ \\
\hline Alcohol & 100 & 211 & 0.9 & $0.5-1.6$ \\
\hline \multicolumn{5}{|l|}{ Maternal exposure } \\
\hline Organic solvents & 11 & 18 & 1.4 & $0.6-3.0$ \\
\hline Smoking & 24 & 48 & 1.1 & $0.6-2.0$ \\
\hline Alcohol & 37 & 84 & 0.9 & $0.6-1.5$ \\
\hline Previous spontaneous abortions & 20 & 22 & 2.0 & $1.0-3.7^{\star}$ \\
\hline Heavy lifting (at work and at home) & 68 & 110 & 1.7 & $1.1-2.7^{*}$ \\
\hline
\end{tabular}

a Each of these models included a variable for potential exposure of the same solvent.

* $\mathrm{P}<0.05,{ }^{* *} \mathrm{P}<0.01$. 


\section{Results}

\section{Spontaneous abortion}

In the analysis, in which confounders were not controlled, likely paternal exposure to organic solvents significantly increased the odds ratio (OR) of spontaneous abortion (OR 2.7) (table 3). For aromatic hydrocarbons the odds ratio was increased at a borderline level of significance (OR 1.6). The odds ratios were significantly increased for xylene (OR 1.8), for the miscellaneous organic solvents, which included thinners (OR 1.7), and for exposure to dusts (OR 2.3). Paternal smoking and alcohol consumption had odds ratios below unity.

Of the maternal variables only heavy lifting (at home and at work combined) (OR 1.7) and the history of previous spontaneous abortion (OR 2.0) gave significantly increased odds ratios. The maternal exposure to organic solvents did not increase the odds ratio (OR 1.4) of spontaneous abortion significantly, neither did maternal smoking or alcohol consumption.

The odds ratio of paternal solvent exposure in general, adjusted for potential confounders (paternal ex- posure to dusts, maternal exposure to organic solvents, heavy lifting, and previous spontaneous abortion) was significantly increased (OR 2.3) (table 4). Maternal lifting also increased the odds ratio significantly (OR 1.7). The odds ratio for dust exposure was not significantly increased when the confounders were controlled.

Table 4. Odds ratio (OR) of spontaneous abortions for paternal solvent exposure - logistic regression analysis. ${ }^{a}(95 \%$ $\mathrm{Cl}=95 \%$ confidence interval)

\begin{tabular}{|c|c|c|c|c|}
\hline \multirow{2}{*}{$\frac{\text { Variable }}{\text { Paternal exposure }}$} & \multicolumn{2}{|c|}{ Cases Referents } & \multirow[t]{2}{*}{ OR } & \multirow[t]{2}{*}{$95 \% \mathrm{Cl}$} \\
\hline & & & & \\
\hline $\begin{array}{l}\text { Organic solvents } \\
\text { Dusts }\end{array}$ & $\begin{array}{r}103 \\
88\end{array}$ & $\begin{array}{l}182 \\
160\end{array}$ & $\begin{array}{l}2.3 \\
1.4\end{array}$ & $\begin{array}{l}1.1-5.0^{*} \\
0.7-2.6\end{array}$ \\
\hline \multicolumn{5}{|l|}{ Maternal exposure } \\
\hline $\begin{array}{l}\text { Organic solvents } \\
\text { Heavy lifting (all) } \\
\text { Previous sponta- } \\
\text { neous abortion }\end{array}$ & $\begin{array}{l}11 \\
68\end{array}$ & $\begin{array}{r}18 \\
110\end{array}$ & $\begin{array}{l}1.2 \\
1.7\end{array}$ & $\begin{array}{l}0.5-2.7 \\
1.0-2.8^{*} \\
0.9-3.4\end{array}$ \\
\hline
\end{tabular}

a The model also included variables controlling missing information and potential solvent exposure.

${ }^{*} \mathrm{P}<0.05$.

Table 5. Odds ratio (OR) of spontaneous abortion for likely paternal exposure to specific solvents according to exposure class - matched logistic regression analysis. (95\% $\mathrm{Cl}=95 \%$ confidence interval)

\begin{tabular}{|c|c|c|c|c|}
\hline Exposure & Cases & Referents & $\mathrm{OR}^{\mathrm{a}}$ & $95 \% \mathrm{Cl}$ \\
\hline \multicolumn{5}{|c|}{ Organic solvents in general } \\
\hline $\begin{array}{l}\text { Low/rare } \\
\text { Intermediate } \\
\text { High/frequent }\end{array}$ & $\begin{array}{l}14 \\
17 \\
72\end{array}$ & $\begin{array}{r}20 \\
44 \\
114\end{array}$ & $\begin{array}{l}2.8 \\
1.8 \\
2.6\end{array}$ & $\begin{array}{l}1.0-7.9^{*} \\
0.7-4.6 \\
1.2-5.9^{*}\end{array}$ \\
\hline \multicolumn{5}{|c|}{ Aromatic hydrocarbons } \\
\hline $\begin{array}{l}\text { Low/rare } \\
\text { Intermediate } \\
\text { High/frequent }\end{array}$ & $\begin{array}{l}13 \\
16 \\
46\end{array}$ & $\begin{array}{l}16 \\
44 \\
72\end{array}$ & $\begin{array}{l}2.1 \\
0.9 \\
1.5\end{array}$ & $\begin{array}{l}0.8-5.6 \\
0.4-2.1 \\
0.7-3.1\end{array}$ \\
\hline \multicolumn{5}{|l|}{ Styrene } \\
\hline $\begin{array}{l}\text { Low/rare } \\
\text { Intermediate } \\
\text { High/frequent }\end{array}$ & $\begin{array}{r}6 \\
12 \\
17\end{array}$ & $\begin{array}{r}9 \\
21 \\
36\end{array}$ & $\begin{array}{l}1.0 \\
0.9 \\
0.7\end{array}$ & $\begin{array}{l}0.3-3.1 \\
0.4-2.1 \\
0.4-1.5\end{array}$ \\
\hline \multicolumn{5}{|l|}{ Toluene } \\
\hline $\begin{array}{l}\text { Low/rare } \\
\text { Intermediate } \\
\text { High/frequent }\end{array}$ & $\begin{array}{r}11 \\
9 \\
28\end{array}$ & $\begin{array}{l}24 \\
27 \\
29\end{array}$ & $\begin{array}{l}0.9 \\
0.7 \\
2.3\end{array}$ & $\begin{array}{l}0.4-2.2 \\
0.3-1.7 \\
1.1-4.7\end{array}$ \\
\hline \multicolumn{5}{|l|}{ Xylene } \\
\hline $\begin{array}{l}\text { Low/rare } \\
\text { Intermediate } \\
\text { High/frequent }\end{array}$ & $\begin{array}{r}7 \\
11 \\
19\end{array}$ & $\begin{array}{l}13 \\
19 \\
29\end{array}$ & $\begin{array}{l}1.2 \\
1.7 \\
1.6\end{array}$ & $\begin{array}{l}0.4-3.3 \\
0.7-4.2 \\
0.8-3.2\end{array}$ \\
\hline \multicolumn{5}{|c|}{ Halogenated hydrocarbons } \\
\hline $\begin{array}{l}\text { Low/rare } \\
\text { Intermediate } \\
\text { High/frequent }\end{array}$ & $\begin{array}{r}14 \\
9 \\
6\end{array}$ & $\begin{array}{l}23 \\
18 \\
19\end{array}$ & $\begin{array}{l}1.1 \\
1.3 \\
0.8\end{array}$ & $\begin{array}{l}0.5-2.6 \\
0.5-3.1 \\
0.3-2.2\end{array}$ \\
\hline \multicolumn{5}{|c|}{ Aliphatic hydrocarbons } \\
\hline $\begin{array}{l}\text { Low/rare } \\
\text { Intermediate } \\
\text { High/frequent }\end{array}$ & $\begin{array}{l}10 \\
13 \\
20\end{array}$ & $\begin{array}{l}25 \\
17 \\
33\end{array}$ & $\begin{array}{l}0.7 \\
1.6 \\
1.3\end{array}$ & $\begin{array}{l}0.3-1.9 \\
0.7-4.0 \\
0.6-2.6\end{array}$ \\
\hline \multicolumn{5}{|c|}{$\begin{array}{l}\text { Miscellaneous organic solvents } \\
\text { (including thinners) }\end{array}$} \\
\hline $\begin{array}{l}\text { Low/rare } \\
\text { Intermediate } \\
\text { High/trequent }\end{array}$ & $\begin{array}{r}9 \\
8 \\
32\end{array}$ & $\begin{array}{l}21 \\
18 \\
36\end{array}$ & $\begin{array}{l}0.9 \\
1.1 \\
2.1\end{array}$ & $\begin{array}{l}0.4-2.5 \\
0.4-3.0 \\
1.1-3.9\end{array}$ \\
\hline
\end{tabular}

a Odds ratios for individual organic solvents, controlled for potential paternal exposure to the same solvent, likely paternal exposure to other organic solvents and dusts, maternal exposure to solvents, maternal heavy lifting (all), and history of previous spontaneous abortion.

* $\mathrm{P}<0.05$. 
Table 6. Odds ratio (OR) of spontaneous abortion in relation to paternal solvent exposure, maternal lifting of heavy burdens, and history of previous spontaneous abortion by the length of the case pregnancy - univariate analysis. $(95 \% \mathrm{Cl}=95 \%$ confidence interval)

\begin{tabular}{|c|c|c|c|c|}
\hline \multirow[t]{2}{*}{ Effect variable } & \multicolumn{2}{|c|}{$\begin{array}{l}\text { Length of the case pregnancy } \\
\qquad 6-10 \text { weeks }\end{array}$} & \multicolumn{2}{|c|}{$\begin{array}{l}\text { Length of the pregnancy } \\
\qquad 11-26 \text { weeks }\end{array}$} \\
\hline & OR & $95 \% \mathrm{Cl}$ & OR & $95 \% \mathrm{Cl}$ \\
\hline Paternal solvent exposure & 2.4 & $0.9-6.5$ & 2.2 & $0.9-5.3$ \\
\hline Maternal heavy liftinga & 2.8 & $1.4-5.8^{\star \star}$ & 0.9 & $0.4-1.9$ \\
\hline $\begin{array}{l}\text { Score } 5-29 \\
\text { Score } \geq 30\end{array}$ & $\begin{array}{l}4.0 \\
2.0\end{array}$ & $\begin{array}{l}1.7-9.4^{\star \star} \\
0.8-4.7\end{array}$ & $\begin{array}{l}0.5 \\
1.5\end{array}$ & $\begin{array}{l}0.2-1.4 \\
0.6-3.6\end{array}$ \\
\hline Previous spontaneous abortion & 4.4 & $1.5-12.6^{\star \star}$ & 0.9 & $0.2-3.5$ \\
\hline
\end{tabular}

a See the Subjects and Methods section for an explanation of the scoring system.

$\star * P<0.01$.

Table 7. Adjusted odds ratio (OR) of spontaneous abortion by paternal occupation - matched multivariate analysis. ${ }^{2}$ (95\% $\mathrm{Cl}=95 \%$ confidence interval $)$

\begin{tabular}{lrrrl}
\hline $\begin{array}{l}\text { Paternal occupation } \\
\text { (exposed to solvents) }\end{array}$ & Cases & Referents & OR & $95 \% \mathrm{Cl}$ \\
\hline Painter & 35 & 46 & 3.3 & $1.6-6.8^{* *}$ \\
Woodworker & 10 & 8 & 3.8 & $1.2-11.9^{*}$ \\
Plastic worker & 21 & 44 & 1.9 & $0.9-4.3$ \\
Metal worker & 10 & 34 & 1.3 & $0.5-3.5$ \\
Other Occupation & 24 & 49 & 2.0 & $0.9-4.3$ \\
\hline
\end{tabular}

a The model contained the previous spontaneous abortion and maternal heavy lifting (at work and at home) as potential confounding factors. nal heavy lifting (at work
$* P<0.05, * * P<0.001$.

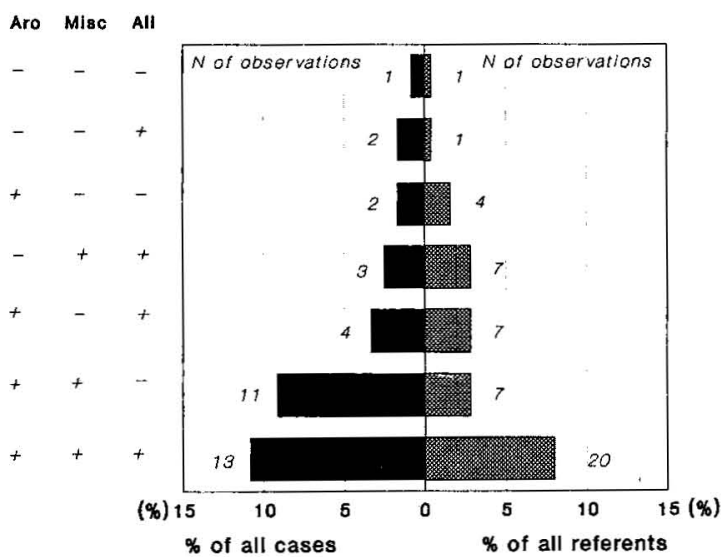

Figure 2. Diagram of the combinations of solvents reported by the painters. (Aro $=$ aromatic, $\mathrm{Misc}=$ miscellaneous, $\mathrm{Ali}=$ aliphatic or halogenated hydrocarbons)

Low/rare and high/frequent exposure to organic solvents and high/frequent exposure to toluene or miscellaneous organic solvents had significantly increased odds ratios (table 5). The odds ratios for styrene, acetone, and halogenated hydrocarbons were below or at unity. For xylene and aliphatic hydrocarbons the odds ratio of the intermediate and high/frequent exposure classes were above unity, but the results did not have statistical significance. In the group of aromatic hydrocarbons the odds ratio was nonsignificantly in- creased in the low/rare and high/frequent exposure classes. The age of the husband or the wife did not relate to the risk of paternal solvent exposure in the interaction model. The proportion of solvent-exposed workers remained unchanged over the study period of 1973-1983. The odds ratio of spontaneous abortion for solvent exposure was slightly greater for the latter half of the study period than for the earlier half, but the difference was not statistically significant.

Lifting heavy burdens increased the odds ratio of early spontaneous abortion ( $\leq 10$ weeks) more than that of the later spontaneous abortions ( $\geq 11$ weeks) (table 6). In the interaction model the difference was statistically significant $(P=0.03)$. In the pregnancies lasting $\leq 10$ weeks no dose-response effect was seen for heavy lifting when the lifting score variable was used. Although the history of previous spontaneous abortion was associated with early abortion $(\leq 10$ weeks), the difference was not significant in the interaction model $(P=0.07)$. The length of the pregnancy did not influence the odds ratio for paternal solvent exposure.

In the analysis by occupation the wives of the painters and wood workers (eg, carpenters in construction, the furniture industry, and the boat industry) had significantly increased odds ratios for spontaneous abortion (table 7). Multiexposure to many solvents or solvent mixtures was common to the study subjects. Many combinations of organic solvents were reported by the painters (figure 2); aromatic hydrocarbons in combination with miscellaneous organic solvents seemed to be responsible for the increased risk of spontaneous abortion.

\section{Congenital malformations}

In the multivariate analysis, in which paternal exposure to dusts and maternal febrile diseases in the first trimester of the pregnancy were considered potential confounders, paternal exposure to organic solvents was not associated with congenital malformations of the child, either when the whole material was included [OR $0.6,95 \%$ confidence interval $(95 \mathrm{CI}) 0.2-2.0$ ] or when luxations of the hip $(\mathrm{N}=7)$ were excluded 
(OR 1.0, $95 \%$ CI 0.2-4.5). For the restricted material (luxations of the hip excluded) the odds ratio was slightly increased for toluene (OR 1.5, $95 \% \mathrm{CI}$ $0.4-5.4$ ), xylene (OR 1.6, $95 \%$ CI 0.4-5.7), and miscellaneous organic solvents (OR 2.0, $95 \%$ CI $0.6-6.1$ ), but none of these findings reached statistical significance.

\section{Discussion}

In this study paternal exposure to organic solvents in general, and to toluene and miscellaneous organic solvents in particular, increased the odds ratio for spontaneous abortion. For xylene the increase was not significant. However, many workers were exposed to multiple solvents (see figure 1), and it may be oversimplified to ascribe risk to a single solvent. For the groups of halogenated and aliphatic hydrocarbons, and for individual solvents like acetone and styrene, no increased risk of spontaneous abortion was found. No significant association with congenital malformations was found, but, because of the small number of cases, no firm conclusions can be drawn.

Exposure to toluene and miscellaneous solvents had a significant effect on spontaneous abortion only when the exposure was high/frequent. The dose-response relationship increased the credibility of the results. However, the odds ratio for aromatic hydrocarbons did not follow the exposure levels in a dose-related manner. Styrene may partially explain this finding since the odds ratios for it were low and there were several styrene-exposed men in the material.

In this study, information on the pregnancy outcome can be considered reasonably reliable since registerbased data on spontaneous abortions and congenital malformations were used $(13,14)$. The pregnancies were also confirmed by the study persons. The confirmation rate for spontaneous abortion $(89.7 \%$ ) was fairly similar to that found for nurses $(90.6 \%)$ and better than that of laundry workers and solvent-exposed female workers (78.4 and 74.1, respectively). (Reviewed in reference 13.) The cases of our study responded slightly more actively than the referents, but the difference was rather small.

Response bias in investigations using the present design to study paternal effects is not very likely. The decrease in the numbers of cases and referents in the final material for analysis was due to the matching procedures, ie, only units formed by a case and one to five referents were accepted. If in one unit the case did not participate, all of its referents were excluded, and vice versa. If no referent of a case responded, the case was excluded. Only one referent was excluded because exposure estimation was not possible on the basis of the available information.

In only a few earlier studies on male reproduction have biological monitoring results been used in ex- posure assessment. More often occupational codes from census data, company records, or birth certificates have been used. (Reviewed in reference 16.) In our study the qualitative assessment of exposure to organic solvents was, in our opinion reliable, since biological monitoring results were available for $75 \%$ of both the cases and the referents assessed as exposed to organic solvents in the spontaneous abortion part of the study. The employer for the time of the studied spermatogenesis was listed in many cases in the laboratory log books. Thus, it was possible to confirm the reported data on the employment through the use of the independent laboratory data. The blind exposure assessment of the unmonitored exposures also reduced the possibility of selective misclassification. A nonselective misclassification cannot be totally excluded however; if present, it would shift the results towards unity.

Because of the high prevalence of solvent exposure among the study population, the statistical power to discover risk associated with exposure was rather high in the final study material for spontaneous abortion. The probability of detecting a twofold risk was $73 \%$, and that of detecting a 1.5-fold risk was $34 \%$ with alpha equal to 0.05 . Yet the small number of unexposed cases was disadvantageous for the study and hindered many of the relevant comparisons. In epidemiologic studies in which multiple comparisons are made, some statistically significant positive findings are expected purely due to chance. Several comparisons were made also in this study, and some of the significant associations might be due to chance.

An association between paternal exposures and spontaneous abortion has been suggested for exposure to anesthetic gases, chlorophrene, vinyl chloride monomer, dibromochloropropane, lead, and metallurgical factory exposures. (Reviewed in reference 17.) Some studies have shown contradictory results, and none have been conclusive. Although exposure to organic solvents in the work environment is common, we have not found earlier reports on the potential effects of paternal solvent exposure on spontaneous abortion. Increased risk of fathering a child with congenital malformation has been connected with paternal occupations in which organic solvent exposure is likely (painters and workers in the printing industry), but neither of these studies were conclusive. (Reviewed in reference 18.) In a Danish study in which the occupational particulars came from birth certificates, painters had a 4.9 times higher risk of fathering a child with a malformation of the central nervous system than other men (4). In our study there were no malformations of the central nervous system among the cases.

Exposure to organic solvents in industrial work is common. In Finland about $40 \%$ of the men working in industry are exposed (19). Therefore, measures to decrease the exposure should be considered already on the basis of existing knowledge. These results remind us of the need to protect men, as well as women, from hazardous occupational exposures. 


\section{Acknowledgments}

We thank Mr P Kyyrönen for his valuable advice concerning the statistical methods and Ms T Nikula for her skillful technical assistance.

This study was supported by grant RO1-OH01919 from the United States National Institute for Occupational Safety and Health.

\section{References}

1. Bjerrehuus T, Detlefsen G. Infertilitet hos danske malere udsat for organiske opløsningsmidler [Infertility in Danish painters exposed to organic solvents]. Ugeskr Læger 1986;148:1105-6. (English summary).

2. Daniell W, Vaughan T. Paternal employment in solvent related occupations and adverse pregnancy outcomes. $\mathrm{Br} J$ Ind Med 1988;45:193-7.

3. Erickson JD, Cochran WM, Anderson CE. Parental occupation and birth defects: a preliminary report. Contrib Epidemiol Biostat 1979;1:107-17.

4. Olsen J. Risk of exposure to teratogens amongst laboratory staff and painters. Dan Med Bull 1983;30:24-8.

5. International Agency for Research on Cancer. Overall evaluations of carcinogenicity: an updating of IARC monographs volumes 1 to 42. Lyon: International Agency for Research on Cancer, 1987. (IARC monographs supplement 7.)

6. Foster P, Creasy D, Foster J, Gray T. Testicular toxicity produced by ethylene glycol monomethyl and monoethyl ethers in the rat. Environ Health Perspect 1984;47:207-18.

7. Welch L, Schrader S, Turner T, Cullen M. Effects of exposure to ethylene glycol ethers on shipyard painters: II. male reproduction. Am J Ind Med 1988;14:509-26.

8. Rasmussen K, Sabroe S, Wohlert M, Ingerslev H, Kappel B, Nielsen J. A genotoxic study of metal workers exposed to trichloroethylene: sperm parameters and chromosome aberrations in lymphocytes. Int Arch Oc- cup Environ Health 1988;60:419-23

9. Dean BJ. Recent findings on the genetic toxicology of benzene, xylenes and phenols. Mutat Res 1985;154: $153-81$.

10. Jelnes JE. Nordisk Ekspertgruppe for grænseværdidokumentation: 82. toluene [Toluene: Nordic Expert Group for documentation on occupational exposure limits]. Stockholm: Arbetarskyddsverket, 1989:1-52. (Arbete och hälsa:3.)

11. Mørck HI, Winkel P, Gyntelberg F. Helbredseffekter af toluenudsættelse [Health effects of exposure to toluene]. Copenhagen: Arbejdsmiljøfondet, 1985:54.

12. Svensson BG, Nise G. Pituitary hormone secretion in occupational toluene exposure. In: Eustace I, ed. XXI international congress on occupational health. Dublin: ETA Publications Ltd, 1984:312.

13. Lindbohm M-L, Hemminki K. Nation-wide data base on medically diagnosed spontaneous abortions in Finland. Int J Epidemiol 1988;17:568 - 73.

14. Saxén L. Twenty years of study of the etiology of congenital malformations in Finland. In: Kalter H, ed. Issues and reviews in teratology; vol 1. New York, NY: Plenum Publishing Co, 1983:73-110.

15. Breslow NE, Day NE. Statistical methods in cancer research; vol 1 (The analysis of case-control studies). Lyon: International Agency for Research on Cancer, 1980.

16. Rosenberg M, Feldblum P, Marshall E. Occupational influences on reproduction: a review of recent literature. J Occup Med 1987;29:584-91.

17. Schrag S, Dixon R. Occupational exposures associated with male reproductive function. Ann Rev Pharmacol Toxicol 1985;25:567-92.

18. Lindbohm M-L, Taskinen H, Hemminki K. Reproductive health of working women. Public Health Rev 1985; 13:55-87.

19. Lehto A-M. Naisten ja miesten työolot [The working conditions of women and men]. Helsinki: Central Statistical Office, 1988:72-3. (Report no 138.)

Received for publication: 21 February 1989 